\title{
The Transglycosylation Activity of the Recombinant Endo- $\beta-N$-Acetylglucosaminidase from Mucor hiemalis in Media Containing Organic Solvents
}

\author{
有機溶媒含有系における Mucor hiemalis 由来 \\ リコンビナントエンド - $\beta-N$ - アセチルグルコサミニダーゼの糖鎖転移活性
}

\author{
Akaike, Eri ; and Yamanoi, Takashi* \\ The Noguchi Institute, 1-8-1 Kaga, Itabashi-ku, Tokyo 173-0003, Japan \\ FAX: 81-3-5944-3213, E-mail: tyama@noguchi.or.jp \\ Key Words: endo- $\beta$ - $N$-acetylglucosaminidase, recombinant Endo- $M$, transglycosylation, organic solvent, \\ disialo biantennary complex-type oligosaccharide
}

\begin{abstract}
We investigated the transglycosylation activity of the recombinant endo- $\beta$ - $\mathrm{N}$-acetylglucosaminidase (Endo-M) from Mucor hiemalis expressed in Candida boidinii in media containing organic solvents, using a disialo biantennary complex-type oligosaccharide from the hen egg yolk glycopeptide as the glycosyl donor and $p$-nitrophenyl $N$-acetyl- $\beta$-D-glucosaminide as the glycosyl acceptor. The recombinant Endo-M had sufficient transglycosylation activity to transfer the oligosaccharide to $p$ NP-GlcNAc in up to $30-40 \%$ organic solvents $(\mathrm{v} / \mathrm{v})$ such as acetone, dimethyl sulfoxide and methanol. The transglycosylation activity in each organic solvent differed from each other. The investigation of the donor concentrations in the organic solvents revealed that the increase in the concentrations significantly increased the transglycosylation yields. Using the Endo-M transglycosylation system in organic solvents, we successfully demonstrated the transglycosylation reaction to the glycosyl acceptors which were sparingly soluble in water such as artificial $\mathrm{N}$-acylated D-glucosamines and a 2-O-glycosylated disaccharide.
\end{abstract}

\section{A. Introduction}

Although the addition of an oligosaccharide to an acceptor is important in glycotechnology, no effective procedure is available. Recently, a practical method for adding an oligosaccharide to a peptide to produce a glycopeptide has been developed using the transglycosylation activity of endo- $\beta-N$-acetylglucosaminidase. Endo- $\beta-N$ acetylglucosaminidases hydrolyze the glycosidic bond in the $N, N$-diacetylchitobiose moiety of the $\mathrm{N}$-linked sugar chains in glycoproteins. Among them, Endo-A from Arthrobacter protophormiae, (1) Endo-M from Mucor hiemalis (2) and Endo-CE from Caenorhabditis elegans (3) have been found to have transglycosylation activity, that is, they can transfer the oligosaccharide blocks of $\mathrm{N}$-linked sugar chains from a
要 約

我々は Candida boidinii で発現させた系状菌 Mucor hiemalis 由来リコンビナントエンド- $\beta-N$ - アセチルグルコサミニダーゼ (リコンビナント Endo-M)の有機溶媒含有系における糖鎖転移 活性について調べた。糖鎖供与体には鷄卵黄由来の糖ぺプチ ドである二本鎖ジシアロ複合型糖鎖を、糖受容体には $p$-ニト ロフェニル $N$-アセチル - $\beta$-D-グルコサミンを用いた。リコン ビナント Endo-M は 30 40\%（v/v)のアセトン、ジメチルス ルホキシド(DMSO)、メタノールを含有する反応系において 十分な糖鎖転移活性を有することがわかった。また、これら の有機溶媒中における本酵素の糖鎖転移活性は、それぞれの 有機溶媒によって特徵が見られた。有機溶媒含有系において 糖鎖供与体の濃度を種々变えたところ、糖鎖転移生成物の収 率が著しく向上することも見出した。次に、この有機溶媒中 での Endo-Mの糖鎖転移反応システムを利用して、 $N$ - アシル グルコサミン誘導体や 2-O-グリコシル二糖化合物といった水 溶性の乏しい化合物を糖受容体に用いた糖鎖転移反応を検討 した。その結果、糖鎖転移反応は速やかに進行し、本 Endo-M 反応システムが有効であることを明らかにした。

A. はじめに

標的となる糖鎖受容体へ糖鎖を付加する技術は糖鎖工学 において重要であるが、有効的な方法はこれまで確立されて いなかった。近年、エンド- $\beta-N-$ アセチルグルコサミニダー ゼの糖鎖転移活性を用いて、糖鎖をぺプチドに導入する糖ぺ プチドの実用的な合成手法が開発されるに至っている。エン ド - $\beta$ - $N$-アセチルグルコサミニダーゼは糖タンパク質の $\mathrm{N}$ - 結 合糖鎖のジアセチルキトビオース部分を加水分解して切断 する䣼素である。その中で、Arthrobacter protophormiae 由来 Endo-A (1)、Mucor hiemalis 由来 Endo-M (2)、Caenorhabditis elegans 由来 Endo-CE（3）に糖鎖転移活性があることが報告さ れている。すなわち、糖ぺプチドあるいは糖タンパクの $\mathrm{N}$ - 結 
glycopeptide or a glycoprotein to suitable acceptors having an $\mathrm{N}$-acetylglucosamine (GlcNAc) residue. Endo-A and Endo-CE can transglycosylate the high-mannose-type oligosaccharides from a glycopeptide or a glycoprotein to the appropriate glycosyl acceptors $(4,5)$. Endo-M can transfer not only the high-mannose-type oligosaccharides, but also the complextype oligosaccharides to the $\mathrm{N}$-acetylglucosamine moieties of the acceptors.

Endo-A and Endo-M are used as effective tools for the reconstruction and remodeling of oligosaccharides from glycopeptides and glycoproteins. Using the transglycosylation activity of Endo-M, Haneda et al. succeeded in adding oligosaccharides to chemically synthesized peptides having $\mathrm{N}$-acetylglucosaminyl-asparagine or -glutamine residues. They chemoenzymatically synthesized biologically important neoglycopeptides having natural $\mathrm{N}$-linked oligosaccharides, such as the glycopeptide derivatives of calcitonin (6), substance $P(7)$, and peptide $T(8)$. This is the only effective method for synthesizing the glycopeptide, and Endo-M has proved to be an efficient tool for the construction of the oligosaccharides (Scheme 1).

Recently, we have conducted several studies on the transglycosylation reaction of the recombinant Endo-M in order to increase the enzyme's utility in glycotechnology. One is the study on the reaction specificity in organic solvents, which we describe in detail in this mini-review. We have also investigated the substrate specificity for oligosaccharide donors, which resulted in an interesting finding that the recombinant Endo-M was able to transfer a bisecting hybridtype oligosaccharide (in Scheme 1) from an ovalbumin glycopeptide (9). The study on the acceptor specificity has
合糖鎖をブロックで $N$-アセチルグルコサミン (GlcNAc) 残基 に転移させる糖鎖転移活性を有している。Endo-A と Endo-CE は糖ペプチドまたは糖タンパクの高マンノース型糖鎖を転移 することができる $(4,5)$ 。Endo-M は高マンノース型糖鎖だけ でなく、複合型糖鎖を糖鎖受容体の $N$ - アセチルグルコサミン 残基に転移させることができる。

Endo-A と Endo-M は糖タンパクあるいは糖ペプチドの糖 鎖の再構築やリモデリングに有用なツールとして利用されて いる。Haneda らは Endo-M の糖鎖転移活性を用いて、N-アセ チルグルコサミニルアスパラギンあるいは、グルタミンを有 する化学的に合成されたペプチドへ天然糖鎖を転移させるこ とに成功しており、カルシトニン（6）、サブスタンス P（7）、 ペプチド T (8)などの生化学的に重要な糖ぺプチドを化学 - 醅 素法により合成している。本手法は効率的に糖ペプチドを合 成できる唯一の方法であり、Endo-M は糖鎖構築における有用 なツールであることが立証されている(スキーム 1$) 。$

最近、我々は糖鎖工学におけるリコンビナント Endo-M 酵 素の利用性を高めるために、本酵素を用いたいくつかの糖鎖 転移反応を検討して、その特異性を解明した。その一つは有 機溶媒中での反応特性で、本ミニレビューで詳細に述べる。 また、我々は本酵素の糖鎖供与体の特異性を検討し、リコン ビナント Endo-M はオバルブミン由来の bisecting 混成型糖鎖 (スキーム 1 中)を転移させる能力があるという興味深い事実 を明らかにした $(9)$ 。糖鎖受容体の特異性に関する研究にお いては、本酵素は C-1 あるいは C-2 が修飾された種々のD-グ

\section{Oligosaccharide Donors}

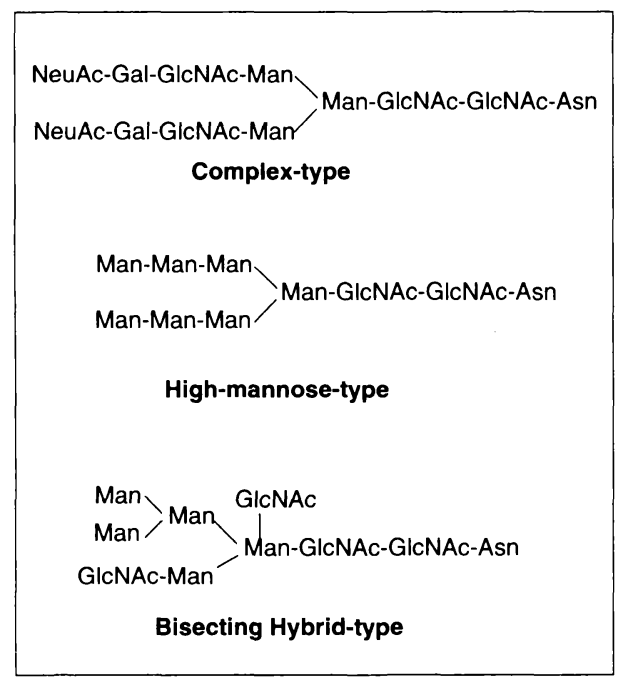

\section{Scheme 1}

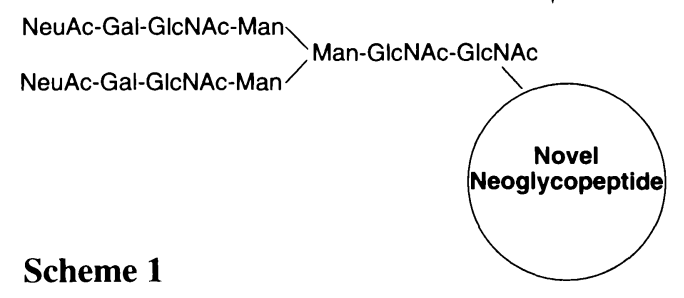


clarified that the enzyme has a transglycosylation activity to a variety of sugar derivatives of D-glucopyranose and D-glucosamine modified at C-1 or C-2 (10). As the application of the Endo-M transglycosylation to the glycoconjugate synthesis, we also successfully prepared the disialo complextype oligosaccharide branched cyclodextrins which were expected to be drug carriers (11).

Fan et al. have investigated the transglycosylation and hydrolytic activities of Endo-A in organic solvents and revealed that the addition of organic solvents, such as acetone, $N, N$ '-dimethylformamide, or dimethyl sulfoxide, to the reaction mixture could enhance the transglycosylation activity and suppress the hydrolytic activity $(12,13)$. Recently, S. Kojima et al. have also reported that the Endo-M transglycosylation system in an organic solvent ( $20 \% \mathrm{v} / \mathrm{v}$ acetonitrile) was useful for preparing the tris-bipyridine ruthenium complexes carrying a disialo complex-type oligosaccharide, which can bind to the type A influenza virus (Scheme 2) (14). However, the detailed transglycosylation activity of Endo-M in the presence of organic solvents has not yet been determined.

We then investigated the transglycosylation activity of Endo-M in organic solvents and clarified that the recombinant Endo-M expressed in Candida boidinii was stable in the
ルコピラノースやD-グルコサミン誘導体に対しても十分な糖 鎖転移活性を有していることを明らかにした $(10)$ 。さらに、 Endo-M の糖転移反応を複合糖質合成に応用した研究では、薬 郕輸送キャリアと期待されるジシアロ複合型糖鎖分岐シクロ デキストリンの合成に成功している(11)。

Fan らは、有機溶媒中での Endo-A の糖鎖転移活性と加水 分解活性を検討している。アセトン、 $N, N$ - ジメチルホルムア ミド、ジメチルスルホキシドなどの有機溶媒を反応系中に添 加すると Endo-A の糖鎖転移活性が向上し、加水分解活性は 抑制されることが明らかにされている(12、13)。また最近、S. Kojima らも、タイプ A のインフルエンザウイルスに結合性の ジシアロ複合型糖鎖を有するトリスビスルテニウム複合体の 合成に有機溶媒中 (20\% v/v アセトニトリル)での Endo-M 糖鎖 転移反応システムが有効であることを報告している(スキーム 2)（14）。しかし、有機溶媒存在下での Endo-M の糖鎖転移活性 の詳細な特性についてはほとんど明らかにされていない。

そこで我々は、有機溶媒中での Endo-M の糖鎖転移活性を 調ベたところ、Candida boidinii で発現させたリコンビナント Endo-Mは、アセトン、メタノール、ジメチルスルホキシドの

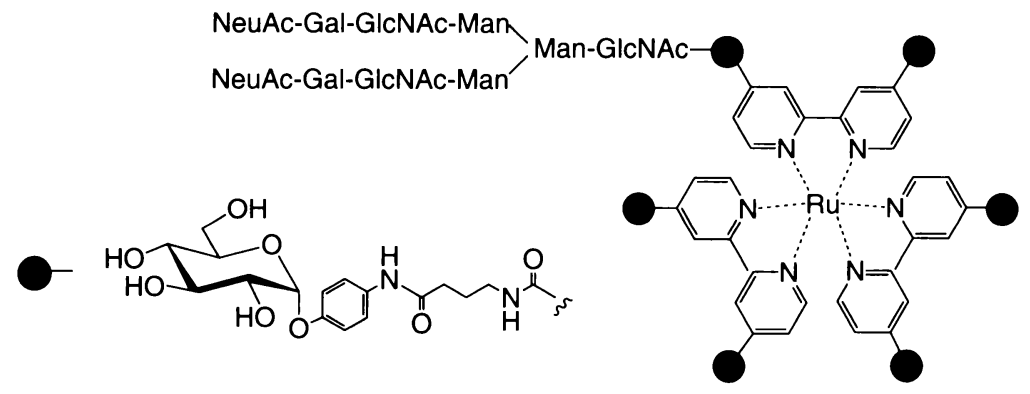

Scheme 2

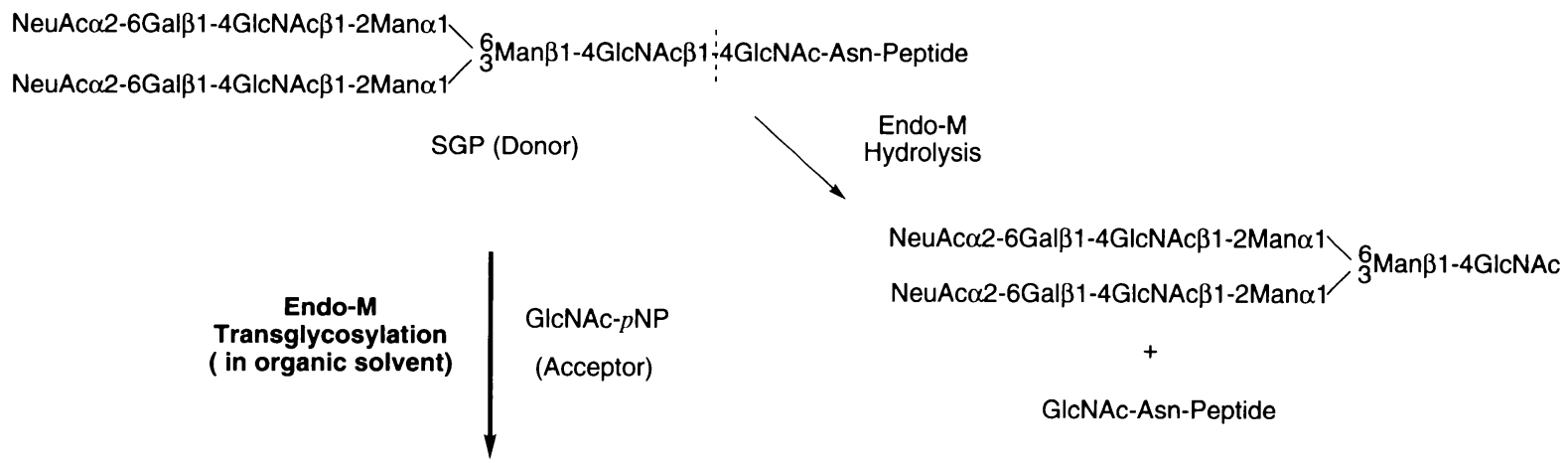

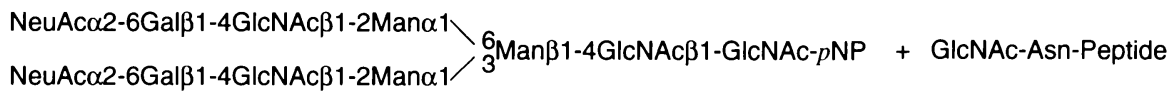

(Transglycosylation product)

Scheme 3 
presence of organic solvents such as acetone, methanol, and dimethyl sulfoxide, and it did not lose its transglycosylation activity (Scheme 3) (15). Using the Endo-M transglycosylation system in organic solvents, we could successfully demonstrate the transglycosylation reaction to several glycosyl acceptors sparingly soluble in water (10). In this review, we describe the specificities of the transglycosylation reaction of the recombinant Endo-M in the presence of organic solvents and the utilization of its transglycosylation system in organic solvents to the water-insoluble glycosyl acceptors.

\section{B. General Transglycoslylation Method with the Recombinant Endo-M}

Recombinant Endo-M was obtained from the cell extract of Candida boidinii (protease deficient (pep4) strain) (16). The glycosyl donor, a sialoglycopeptide having a disialo biantennary complex-type oligosaccharide: H-Lys-Val-AlaAsn[(NeuAc-Gal-GlcNAc-Man) ${ }_{2}$-Man-GlcNAc $\left.{ }_{2}\right]$-Lys-Thr$\mathrm{OH}$, called SGP, was prepared from hen egg yolk according to the reported method (17).

The transglycosylation reaction was performed with a reaction mixture composed of $0.1 \mu$ mol of pNP- $\beta$-D-GlcNAc, $0.2 \mu \mathrm{mol}$ of SGP, and $1.48 \mathrm{mU}$ of Endo-M in a total volume of $10 \mu \mathrm{L}$ of $60 \mathrm{mM}$ potassium phosphate buffer $(\mathrm{pH} 6.25)$ containing $0-50 \%$ of various organic solvents $(\mathrm{v} / \mathrm{v})$. After incubation for $0.5-3 \mathrm{~h}$ at $25^{\circ} \mathrm{C}$, the reaction was terminated by the addition of $490 \mu \mathrm{L}$ of a $0.2 \%$ trifluoroacetic acid solution.

The transglycosylation was done at a low temperature to obtain reliably reproducible data when low boiling organic solvents were used. We have ascertained that the transglycosylation activity of the recombinant Endo-M in water at $25^{\circ} \mathrm{C}$ was almost similar to that at $37^{\circ} \mathrm{C}$.

Analyses of the transglycosylation products were done using HPLC. The transglycosylation products were confirmed by a MALDI-TOF mass spectrometric analysis.

\section{Transglycosylation Activity and Stability of the Recombinant Endo-M in Various Organic Solvents}

We examined the transglycosylation activity of the recombinant Endo-M in various organic solvents using $10 \mathrm{mM}$ of pNP- $\beta$-D-GlcNAc and $20 \mathrm{mM}$ of SGP (Scheme $3)$. The reaction mixture was incubated with the enzyme at $25{ }^{\circ} \mathrm{C}$ for $1 \mathrm{~h}$ (or $3 \mathrm{~h}$ ) in various $30 \%$ organic solvents (v/v) such as acetone, butanone, acetonitrile, dioxane, $\mathrm{N}, \mathrm{N}$ dimethylformamide (DMF), dimethyl sulfoxide (DMSO), methanol, or tetrahydrofuran (THF). These results are shown in Table I. In the $30 \%$ acetone solution, the yield of the transglycosylation product was found to reach $41 \%$ (34\%) of the total amount of pNP- $\beta$-D-GlcNAc as the acceptor. Moreover, the yields of the transglycosylation products reached $31 \%(21 \%)$ and $37 \%(25 \%)$ in DMSO and methanol,
有機溶媒の存在下で安定であり、かつ糖鎖転移活性が損なわ れないという事実を見出した(スキーム3)（15）。この有機溶媒 中での Endo-M 糖鎖転移反応システムを用いて、難水溶性のい くつかの化合物への糖鎖転移反応にも成功した(10)。本ミニ レビューでは、有機溶媒存在下でのリコンビナント Endo-M の 糖鎖転移反応の特性、および有機溶媒中での Endo-M 糖鎖転移 反応システムの水溶性の乏しい化合物への利用について述べ る。

\section{B. リコンビナント Endo-M を用いた糖鎖転移反応の一般的方法}

リコンビナント Endo-M は Candida boidinii（プロテアー ゼ欠損株(pep4))の細胞抽出物より得た(16)。糖鎖供与体は、 2 本鎖ジシアロ複合型糖鎖を有するシアログリコペプチド、 H-Lys-Val-Ala-Asn[(NeuAc-Gal-GlcNAc-Man) ${ }_{2}$-Man-GlcNAc ${ }_{2}$ Lys-Thr-OH（SGP）を文献の方法に従い鷄卵黄から調製した (17)。糖鎖転移反応は pNP- $\beta$-D-GlcNAc を $0.1 \mu \mathrm{mol} 、$ SGP 0.2 $\mu \mathrm{mol} 、$ Endo-M 酵素を $1.48 \mathrm{mU}$ 用い、0 $50 \%$ の有機溶媒を含 有する $60 \mathrm{mM}$ リン酸カリウム編衝液( $\mathrm{pH}$ 6.25)を用いて、全量

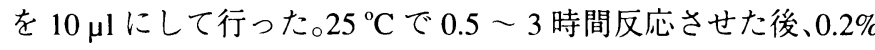
トリフルオロメタンスルホン酸を $490 \mu \mathrm{L}$ 添加して反応を停止 した。

低沸点の有機溶媒を使用した時に、信頼性のある再現性 デー夕を得るために糖鎖転移反応は、 $25^{\circ} \mathrm{C}$ という低い温度で 行った。ちなみに、我々は $25^{\circ} \mathrm{C}$ の水溶液中でのリコンビナン 卜 Endo-M の糖鎖転移活性は $37^{\circ} \mathrm{C}$ で行った反応とほとんど変 わらないということを確認している。

糖鎖転移生成物の分析はHPLCで行い、同定はMALDITOF マススペクトルで行った。

\section{C. 様々な有機溶媒中でのリコンビナント Endo-M の糖鎖転移} 活性と安定性

糖鎖受容体に $10 \mathrm{mM}$ pNP-GlcNAc、糖鎖供与体に $20 \mathrm{mM}$ SGP を用い、種々の有機溶媒中での Endo-M 酵素の糖鎖転移

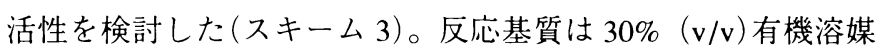
含有水溶液中で、 $25^{\circ} \mathrm{C}$ で 1 時間(あるいは 3 時間) 擋拌した。 有機溶媒はアセトン、ブタノン、アセトニトリル、ジオキサ ン、 $N, N$ - ジメチルホルムアミド(DMF)、ジメチルスルホキシ ド(DMSO)、メタノール、テトラヒドロフラン $(\mathrm{THF}) を$ 用い た。その結果を表Iに示す。30\%アセトン含有溶液中におけ る転移反応生成物の収率は、添加した糖鎖受容体である pNP $\beta$-D-GIcNAcの全量から換算して $41 \%$ （34\%）に達することが わかった。さらに、DMSOおよびメタノール溶液を用いた糖 鎖転移生成物の収率は、それぞれ $31 \%(21 \%) 、 37 \%(25 \%)$ 
Table I. The yields of the transglycosylation product incubated for $1 \mathrm{~h}$ and $3 \mathrm{~h}$ in the presence of various $30 \%$ organic solvents $(\mathrm{v} / \mathrm{v})$.

\begin{tabular}{ccc}
\hline \multirow{2}{*}{ organic solvent } & \multicolumn{2}{c}{ transglycosylation yield (\%) } \\
\cline { 2 - 3 } & $1 \mathrm{~h}$ & $3 \mathrm{~h}$ \\
\hline none & 37 & 15 \\
acetone & 41 & 34 \\
butanone & 0 & 0 \\
acetonitrile & 0 & 0 \\
dioxane & 0 & 0 \\
DMF & 0 & 0 \\
DMSO & 31 & 21 \\
methanol & 37 & 25 \\
THF & 0 & 0 \\
\hline Acceptor: $p$ NP- $\beta$-D-GlcNAc. Donor: SGP
\end{tabular}

respectively. We could not observe the transglycosylation product in $30 \%$ acetonitrile solution, although Kojima et al. reported the transglycosylation in $20 \%$ acetonitrile (14). On the other hand, the yield was $37 \%$ (only $15 \%$ ) for the reaction in an aqueous solution.

Thus, the recombinant Endo-M showed sufficient transglycosylation activity in several organic solvents. Furthermore, all evidence points to the fact that the recombinant Endo-M is likely to be extremely stable in these organic solvents.

The mass value of the transglycosylation product of pNP-(GlcNAc) $)_{2}$-Man-(Man-GlcNAc-Gal-NeuAc) ${ }_{2}$ was determined by a MALDI-TOF mass spectrometric analysis. pNP-(GlcNAc) ${ }_{2}$-Man-(Man-GlcNAc-Gal-NeuAc) ${ }_{2}$ : found $\mathrm{m} / \mathrm{z}$ [M-H]' 2340.7, calcd for $\mathrm{C}_{90} \mathrm{H}_{141} \mathrm{~N}_{7} \mathrm{O}_{64}[\mathrm{M}-\mathrm{H}]^{-} 2342.8$.

\section{The Effect of the Acetone Concentration on the Transglycosylation Activity of the Recombinant Endo-M}

The effect of the acetone concentration $(0-50 \%)$ on the
であった。先に述べたように、Kojimaらは20\%アセトニトリ ル含有水溶液中において糖鎖転移反応を報告しているが(14)、 我々は 30\%アセトン含有系では転移生成物を確認できなかっ た。一方で、有機溶媒を添加しない水系での反応は 37\%（僅 か 15\%)の収率でしかなかった。

このことから、リコンビナント Endo-Mは、有機溶媒中 においても十分な糖鎖転移活性を有していることが明らかに なった。このような事実から、本酵素は上のこの有機溶媒中 で極めて安定性が高いことも示唆された。

糖鎖転移生成物は、MALDI-TOF 質量分析により確認した。 生成物である pNP-(GIcNAc) - Man-(Man-GlcNAc-Gal-NeuAc) の分子量の実測値は $\mathrm{m} / z$ [M-H] 2340.7 、理論值は $\mathrm{C}_{90} \mathrm{H}_{141} \mathrm{~N}_{7} \mathrm{O}_{64}$ [M-H] 2342.8. である。

\section{D. アセトンの濃度変化がリコンビナント Endo-M の糖鎖転移 活性に及ぼす効果}

リコンビナント Endo-M の糖鎖転移活性に及ほすアセトン

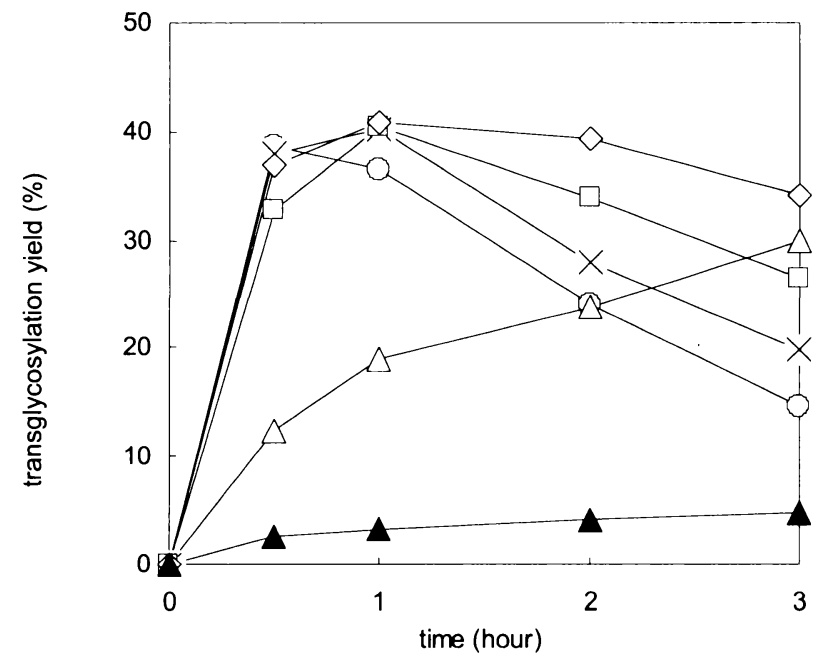

Fig. 1. The effect of the acetone concentration in the range of $0-50 \%(\mathrm{v} / \mathrm{v})$ on the transglycosylation activity. $(\bigcirc, 0 \% ; \times, 10 \% ; \square, 20 \% ; \diamond, 30 \% ; \triangle, 40 \% ; \Delta, 50 \%)$ 
transglycosylation activity of the recombinant Endo-M was investigated. These results are shown in Fig. 1. According to the reaction process results, it appeared that the degradation of the product scarcely occurred in the organic solvent, although it occurred rather rapidly in aqueous solution. The yields of the transglycosylation product reached about $40 \%$ after a 1-h incubation in $10-30 \%$ acetone concentrations. The enzyme had sufficient transglycosylation activity in up to $30 \%$ acetone concentrations.

However, it might be expected that the enzyme was inactivated after a 1-h incubation. In order to investigate whether the enzyme was active after a 1-h incubation, pNP$\beta$-D-GlcNAc and SGP were added to the reaction mixture incubated with the enzyme in a $30 \%$ acetone concentration for 1-h. The yield of the transglycosylation product reached $40 \%$ 2 hours after adding the substrates. This result showed that the enzyme was active after incubation in the $30 \%$ acetone for 1-h.

\section{E. The Transglycosylation Activity of the Recombinant Endo-M in DMSO and Methanol}

The effect of the DMSO and methanol concentrations $(0-50 \%)$ on the transglycosylation activity of the recombinant Endo-M was also investigated. In these organic solvents, the enzyme indicated sufficient transglycosylation activity in up to $40 \%$ concentrations. The yields of the transglycosylation product reached about $30 \%$ after 3 hours. These results are summarized in Fig. 2.

\section{F. The Effect of the Oligosaccharide Donor (SGP) Concentration on the Transglycosylation Yield}

The effect of the sugar-chain donor concentration on the yield of the transglycosylation product was examined.
濃度 $(0 \sim 50 \%$ 含有 $)$ の効果について検討した。その結果を図 1 に示す。反応時間が経過するにつれて、水系の反応では糖鎖 転移生成物の速やかな減少が見られたのに対し、有機溶媒を 添加した反応系では生成物の減少がそれほど顕著に見られな いことがわかった。10～30\%アセトン含有系では、転移生成 物の収率は、1 時間反応後に約 $40 \%$ に達した。本酵素が $30 \%$ までのアセトン含有系において十分な糖鎖転移活性をもつこ とがわかった。しかし、反応の 1 時間後には酵素が失活して いる可能性も考えられた。そこで、1 時間後にEndo-M が失活 しているかどうかを調べるために、30\% アセトン含有系で酵 素を 1 時間曝した反応系に、pNP- $\beta$-D-GIcNAc と SGP を加える 実験を行った。その結果、これらの基質を加えてから、2 時間 後に糖鎖転移生成物の収率は $40 \%$ に達した。このことから、 本酵素を $30 \%$ アトン含有系に 1 時間入れておいても酵素活 性は損なわれないことがわかった。

\section{E. DMSO とメタノール含有系でのリコンビナント Endo-Mの 糖鎖転移活性}

次に、DMSO とメタノール $(0 \sim 50 \%)$ 含有系でのリコンビ ナント Endo-Mの糖鎖転移活性を調べた。本酵素は、これらの 有機溶媒を $40 \%$ 濃度で含有する反応系においても充分な糖鎖 転移活性を持つことがわかった。3 時間反応後の糖鎖転移収率 は約 30\% にまで達した。これらの結果は図 2 に示した。

\section{F. 糖鎖供与体（SGP）の濃度が糖鎖転移収率へ及ぼす効果}

糖鎖供与体 SGP の濃度が糖鎖転移収率に及ほす効果を 調べた。これらの結果は表 II にまとめた。40 mMSGPを用

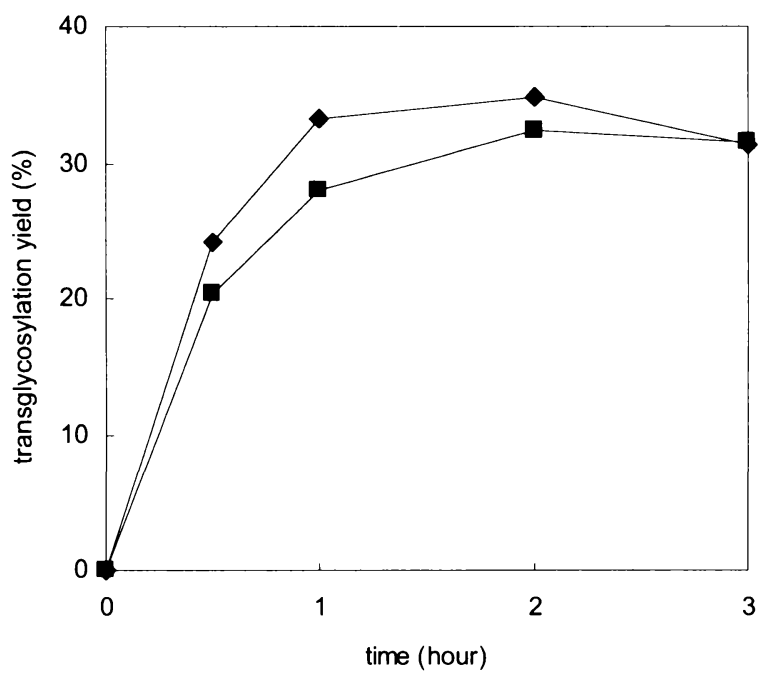

Fig. 2. The effect of the organic solvent concentration on the transglycosylation activity. (, $40 \% \mathrm{DMSO} ; \bullet, 40 \% \mathrm{MeOH})$ 
Table II. The effect of various SGP concentrations on the yields of the transglycosylation product incubated for $2 \mathrm{~h}$ in various $30 \%$ organic solvents $(\mathrm{v} / \mathrm{v})$.

\begin{tabular}{cccc}
\hline \multirow{2}{*}{ SGP $(\mathrm{mM})$} & \multicolumn{3}{c}{ Yield (\%) } \\
\cline { 2 - 4 } & acetone & methanol & DMSO \\
\hline 20 & 39 & 32 & 29 \\
40 & 60 & 50 & 48 \\
80 & 60 & 63 & 60 \\
\hline
\end{tabular}

Acceptor: $p$ NP- $\beta$-D-GlcNAc. Donor: SGP

These results are summarized in Table II. The incubation with $40 \mathrm{mM}$ of SGP in $30 \%$ acetone for $2 \mathrm{~h}$ raised the transglycosylation yield to about $60 \%$. The maximum attained yield was about $66 \%$ after $3 \mathrm{~h}$ in each reaction mixture, including $30 \%$ acetone, methanol or DMSO using $80 \mathrm{mM}$ of SGP.

\section{G. The Transglycosylation on the Compound Sparingly Soluble in Water}

Using the above Endo-M transglycosylation system in organic solvents, we attempted the transglycosylation on the artificial $\mathrm{N}$-acylated $\mathrm{D}$-glucosamine derivatives such as 2-deoxy-2,2'-naphthoamido-D-glucopyranose (1) and 2-benzyloxycarbonylamino-2-deoxy-D-glucopyranose (2), and on the 2-O-glycosylated disaccharide (called naringin 3), which were sparingly soluble in water. These compounds
い $30 \%$ アトン中で 2 時間反応させたところ、糖鎖転移収率 は60\%に達した。 $80 \mathrm{mMSGP}$ の使用時には、30\%アセトン、 DMSO、メタノールのいずれの有機溶媒を用いても、3 時間後 に収率は最大約 $60 \%$ に達するがわかった。

\section{G. 水溶性の乏しい化合物への糖鎖転移反応の応用}

以上述べてきた有機溶媒中での Endo-M 糖鎖転移反応シ ステムを利用して、水に溶解性のそしい化合物への糖鎖転移 反応を検討した。糖鎖受容体には、 $N$ - アシル D-グルコサミン 誘導体として、2-デオキシ -2,2'-ナフトアミド-D-グルコピラ ノース(1)や2-ベンジルオキシカルボニルアミノ -2-デオキシ

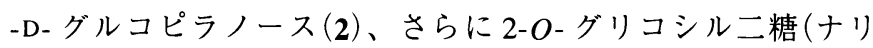
ンギン、3)を用いた。Endo-MがD-グルコピラノースと D-グ

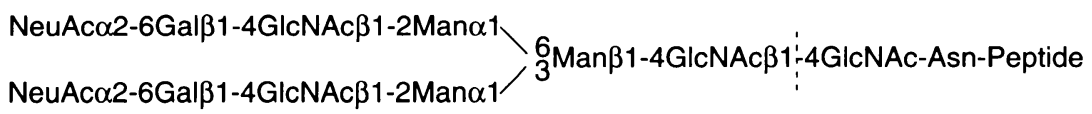

(Donor: SGP)
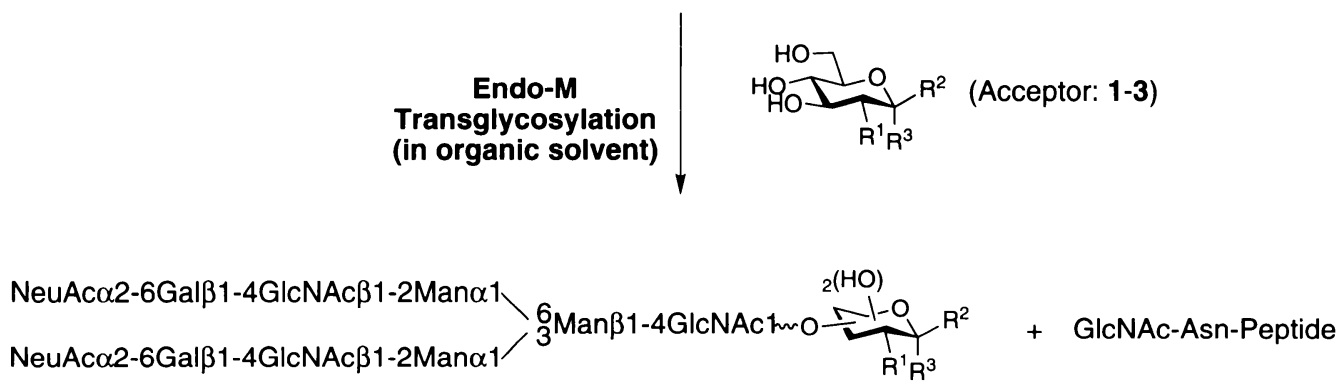

(Transglycosylation product)

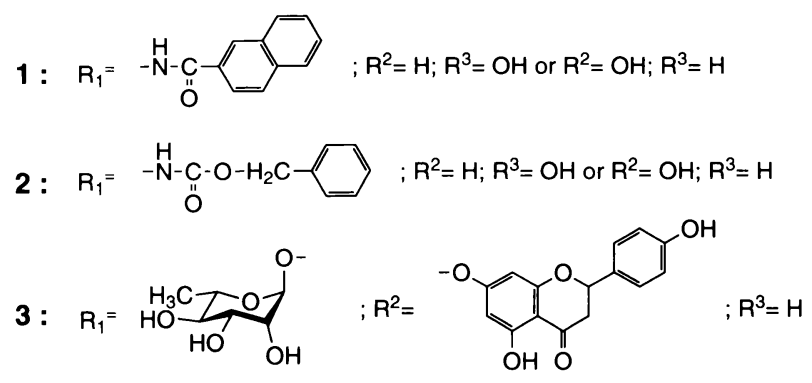

Scheme 4 
Table III. The application of the Endo-M transglycosylation system in organic solvents to various sugar derivatives (1-3) sparingly soluble in water and the mass values of the obtained transglycosylation products.

\begin{tabular}{cccc}
\hline Acceptor & Transglycosylation yield $(\%)$ & Found $\mathrm{m} / \mathrm{z}[\mathrm{M}-\mathrm{H}]^{-}$ & Calcd for $[\mathrm{M}-\mathrm{H}]^{-}$ \\
\hline 1 & 17 & 2332.2 & 2333.8 \\
2 & 24 & 2312.0 & 2313.8 \\
3 & 38 & 2579.2 & 2580.9 \\
\hline
\end{tabular}

The incubation with the sugar derivative $(10 \mathrm{mM})$ and SGP $(20 \mathrm{mM})$ was carried out at 37 ${ }^{\circ} \mathrm{C}$ for $3 \mathrm{~h}$ in potassium phosphate buffer (pH 6.25) containing $30 \%$ DMSO.

were chosen on the basis of the assumption that Endo-M would have a transglycosylation activity for sugar derivatives of D-glucopyranose and D-glucosamine modified at C-1 or C-2 (Scheme 4). The enzymatic reaction was carried out with $10 \mathrm{mM}$ of the glycosyl acceptor and $20 \mathrm{mM}$ of SGP in $30 \%$ DMSO solution for $3 \mathrm{~h}$. The reaction was done at $37{ }^{\circ} \mathrm{C}$ in order to increase the solubilities of these glycosyl acceptors. These enzymatic reactions in $30 \%$ DMSO successfully produced the transglycosylation products with satisfactory yields. The mass values of the transglycosylation products were determined by MALDI-TOF mass spectrometric analyses. These results are listed in Table III.

\section{H. Conclusion}

As described above, the enzymatic reactions using the recombinant Endo-M expressed in Candida boidinii proceeded in media containing 30-40\% of organic solvents such as acetone, DMSO, and methanol. This means that the recombinant Endo-M is stable in the presence of these organic solvents without losing its transglycosylation activity, and is applicable to compounds sparingly soluble in water. Using the Endo-M transglycosylation system in organic solvents, we could successfully demonstrate the transfer of a disialo complex-type oligosaccharide to several water-insoluble compounds. The recombinant Endo-M has recently become commercially available from Tokyo Kasei Kogyo Co., Ltd. We believe our study will contribute to the utilization of Endo-M for the syntheses of various useful glycoconjugates.

\section{Acknowlegement}

We are gratefully indebted to Professor Kenji Yamamoto (Kyoto University) for the kind gift of the recombinant Endo-M and for his very helpful discussions.
ルコサミンの C-1 または C-2 を化学的に修飾した糖誘導体に 対して糖鎖転移活性を発現するとの仮説に基づき、これらの 化合物を選んだ(スキーム 4)。酵素反応は $10 \mathrm{mM}$ 糖鎖受容体、 $20 \mathrm{mM}$ 糖鎖供与体 SGP を用いて、30\%DMSO 含有系で 3 時 間擋拌し、反応温度はこれら糖鎖受容体の溶解性を高めるた め $37{ }^{\circ} \mathrm{C}$ で行った。30\% DMSO 含有系において、本反応はいず れの化合物でも十分な収率で糖鎖転移生成物を与えることが わかった。糖鎖転移生成物の同定は MALDI-TOF 質量分析で 行った。これらの結果は表 III に示した。

\section{H. まとめ}

以上述べたように、Candida boidinii で発現させたリコンビ ナント Endo-M は、30～40\% 濃度のア七トン、DMSO、メ夕 ノールを含む反応系において糖鎖転移反応を進行させる能力 を持つことがわかった。このことは、リコンビナント Endo-M がこれらの有機溶媒存在下で糖鎖転移活性を損なうことなく、 安定であり、また水溶性の乏しい化合物を糖鎖受容体に利用 できることを示している。有機溶媒中での Endo-M 糖鎖転移反 応システムを利用して、水溶性のそしい化合物へのジシアロ 複合型糖鎖の転移に成功した。リコンビナント Endo-M 酵素は 現在、東京化成工業株式会社により販売されている。Endo-M 酵素が今後、様々な有用な複合糖質の合成に利用されるに際 し、我々の研究が大いに役立つものと確信している。

\section{謝 辞}

リコンビナントEndo-M 酵素をご提供、ならびに研究をご 指導いただきました山本憲二教授(京都大学)に深く感謝致し ます。

\section{References}

1. Takegawa, K., Yamaguchi, S., Kondo, A., Kato, I., and Iwahara, S. (1991) Biochem. Int. 25, 829-835

2. Yamamoto, K., Kadowaki, S., Watanabe, J., and Kumagai, H. (1994) Biochem. Biophys. Res. Commun. 203, $244-252$

3. Kadowaki, S., Yamamoto, K., Fujisaki, M., Izumi, K., Tochikura, T., and Yokoyama, T. (1990) Agric. Biol. Chem. 54, $97-106$

4. Takegawa, K., Nakoshi, M., Iwahara, S., Yamamoto, K., and Tochikura, T. (1989) Appl. Environ. Microbiol. 55, 3107-3112

5. Kato, T., Fujita, K., Takeuchi, M., Kobayashi, K., Natsuka, S., Ikura, K., Kumagai, H., and Yamamoto, K. (2002) Glycobiology 12, 581587 
6. Haneda, K., Inazu, T., Mizuno, M., Iguchi, R., Yamamoto, K., Kumagai, H., Aimoto, S., Suzuki, H., and Noda, T. (1998) Bioorg. Med. Chem. Lett. 8, 1303-1306

7. Haneda, K., Inazu, T., Mizuno, M., Iguchi, R., Tanabe, H., Fujimori, K., Yamamoto, K., Kumagai, H., Tsumori, K., and Munekata, E. (2001) Biochim. Biophys. Acta 1526, 242-248

8. Haneda, K., Inazu, T , Mizuno, M., Yamamoto, K., Fujimori, K., and Kumagai, H. (1996) Peptide Chemistry; Kitada, C.(1997) Protein Research Foundation, pp 13-16

9. Osumi, K., Makino, Y., Akaike, E., Yamanoi, T, Mizuno, M., Noguchi, M., Inazu, T., and Yamamoto, K., Fujita, K. (2004) Carbohydr. Res. 339, 2633-2635

10. Yamanoi, T., Tsutsumida, M., Oda, Y., Akaike, E., Osumi, K., Yamamoto, K., and Fujita, K. (2004) Carbohydr. Res. 339, 1403-1406

11. Yamanoi, T, Yoshida, N., Oda, Y., Akaike, E., Tsutsumida, M., Kobayashi, N., Osumi, K., Yamamoto, K., Fujita, K., Takahashi, K., and Hattori, K. (2005) Bioorg. Med. Chem. Lett. 15, 1009-1013

12. Fan, J.-Q., Takegawa, K., Iwahara, S., Kondo, A., Kato, I., Abeygunawardana, C., and Lee, Y.C. (1995) J. Biol. Chem. 270, $17723-17729$

13. Fan, J.-Q., Quesenberry, M.S., Takegawa, K., Iwahara, S., Kondo, A., Kato, I., and Lee, Y.C. (1995) J. Biol. Chem. 270, 17730-17735

14. Kojima, S.; Hasegawa, T., Yonemura, T., Sasaki, K., Yamamoto, K., Makimura, Y., Takahashi, T., Suzuki, T., Suzuki, Y., and Kobayashi, K. (2003) Chem. Commun., 1250-1251

15. Akaike, E., Tsutsumida, M., Osumi, K., Fujita, M., Yamanoi, T., Yamamoto, K., and Fujita K. (2004) Carbohydr. Res. 339, 719-722

16. Fujita, K., Kobayashi, K., Iwamatsu, A., Takeuchi, M., Kumagai, H., and Yamamoto, K. (2004) Arch. Biochem. Biophys. 432, $41-49$

17. Seko, A., Koketsu, M., Nishizono, M., Enoki, Y., Ibrahim, H.R., Juneja, L.R., Kim, M., and Yamamoto, T. (1997) Biochim. Biophys. Acta 1335, 23-32

Received on September 29, 2005, accepted on December 14, 2005

\section{Profile of the Authors}

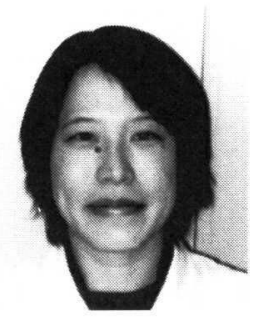

Eri Akaike graduated from the Faculty of Biotechnology and Life Science, Tokyo University of Agriculture and Technology, and received her masters degree in 2001. She joined the Noguchi Institute in 2001. Now she is working at the laboratory of Dr. Takashi Yamanoi in the Noguchi Institute and investigates transglycosylation reaction using endoglycosidases.

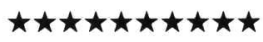

Takashi Yamanoi graduated from the Department of Chemistry, Tokyo University of Science in 1985 (MS), and started his career in the carbohydrate field as the research scientist at the Noguchi Institute. He obtained his Ph.D. from Tokyo University of Science in 1995. He has been a chief Scientist of the Synthetic Carbohydrate Chemistry Laboratory at The Noguchi Institute since 2002, and also teaches as a part-time lecturer in Meiji University. 